Misimović, M., Zavišić, N., Žabić, M., Maličević, Z. (2021): Influence of foliar fermented plant infusions on organically grown blackberry. Agriculture and Forestry, 67(3): 109-119

DOI: 10.17707/AgricultForest.67.3.09

\begin{abstract}
Milutin MISIMOVIĆl, Nada ZAVIŠI $\check{C}^{2}$, Mirjana $\breve{Z} A B I C^{3}$, Zoran MALIČEVIĆ
\end{abstract}

\title{
INFLUENCE OF FOLIAR FERMENTED PLANT INFUSIONS ON ORGANICALLY GROWN BLACKBERRY
}

\section{SUMMARY}

The aim of this study was to examine the influence of nettle, dandelion and alfalfa infusions on the content of soluble dry matter and the dry matter yield of organically grown blackberry fruit. The fermentation period during the preparation of plant infusions was 14 and 21 days. First treatment with plant infusions was performed in mid-May, followed by treatments every 10 to 15 days. The treatments were conducted until the appearance of the first ripe blackberry fruits. The soil on which the blackberry plantation was established was analyzed, as well as the chemical composition of plant infusions, the content of soluble dry matter and the dry matter yield of blackberry fruit.

The soil was slightly alkaline. The contents of heavy metals lead and cadmium in soil were below the limit allowed for the soil intended for organic production. After 14 and 21 days of fermentation, the $\mathrm{pH}$ value and the content of nitrogen, phosphorus and potassium in the infusions was determined. The $\mathrm{pH}$ value of the nettle infusion was mildly acidic, while of dandelion and alfalfa infusions it was acidic. The highest content of soluble dry matter in ripe blackberry fruits was found in the treatment with dandelion infusion fermented for 21 days $(9.51 \%)$, and the lowest in the treatment with 21 days fermented alfalfa infusion $(8.80 \%)$. Statistically highly significant difference in the content of soluble dry matter was found in blackberry fruits treated with alfalfa infusions fermented for 14 days (F-14) and 21 days (F-21). The dry matter yields of blackberry fruits per unit area in treatment with F-14 nettle and dandelion infusions were higher than when treated with F-21 infusions. The opposite was obtained with the alfalfa infusion treatment, i.e., higher yield of fruit dry matter was achieved with F-21 treatment. The highest dry matter yield was obtained with the application of alfalfa F-21 infusion and amounted to $1327.4 \mathrm{~kg} \mathrm{ha}^{-1}$. Statistically highly significant differences in the dry matter yield of blackberry

\footnotetext{
${ }^{1}$ Misimovič M Department of Economy and Agriculture, Gradiška Municipality, Republic of Srpska, Bosnia \& Herzegovina

${ }^{2}$ Zavišić N PI Agricultural Institute of Republic of Srpska, Banja Luka, Bosnia \& Herzegovina

2Žabić M, (corresponding author: mirjana.zabic@agro.unibl.org), Maličević Z, Faculty of

Agriculture, University of Banja Luka, Bosnia \& Herzegovina

Notes: The authors declare that they have no conflicts of interest. Authorship Form signed online.

Recieved:12/05/2021

Accepted:06/09/2020
} 
fruits were found between the control treatment and treatments with the F-14 and F-21 alfalfa infusions.

Keywords: blackberry, organic production, plant infusions, dry matter yield

\section{INTRODUCTION}

Production of safe food without the use of pesticides, while preserving biodiversity and biological activity of the soil, is the basic goal of organic agriculture. With this method of food production, the application of mineral fertilizers must be eliminated from the production cycle. In such circumstances, in order to avoid a reduction in yield, there is a growing need for usage of organic fertilizers instead of mineral ones. Among organic fertilizers, foliar organic fertilizers, which can be used during the entire vegetation, are especially important. Care should be taken when using organic fertilizers, because their untimely and excessive use, due to intensive mineralization, can cause some negative consequences. Due to the negative consequences that can occur with the application of organic fertilizers, the use of foliar organic fertilizers is becoming more popular with organic food producers, because they simultaneously provide them with healthy products and enable the preservation of the environment.

By using infusions made from different plants, producers can expect a high-quality yield and good positioning on the market. At the same time, the use of organic foliar fertilizers does not have a negative impact on the natural environment. The use of organic foliar fertilizers essentially supports the concept of self-sustainable agriculture, in which fruit growing based on the principles of organic agriculture, has a significant place. It has been reported that after several treatments of plants with organic foliar fertilizers an increase in yield was observed, but also an improvement in the nutritional value of harvested fruits (Hoitink et al. 1997, Quarles, 2001). In a very short time, foliar fertilization can compensate for the lack of macro and micro elements that are not absorbed in sufficient quantities through the roots (Boshev et al. 2016). Foliar fertilizers are directly absorbed through the leaves and in limited quantities, unlike fertilizers that are absorbed through the soil (Fernandez and Eichert 2009).

A large number of plant species which can be used for preparation of quality foliar plant infusions grow freely in nature. Plant infusions, in addition to providing the plant with a sufficient amount of easily accessible nutrients, have partly insecticidal and fungicidal action due to the bioactive chemicals contained in them (Kim et al. 2005, Daoubi et al. 2005).

Having in mind the fact that plant infusions are environmentally friendly and do not pollute the environment, the undertaken research could make a significant contribution to the improvement of organic fruit growing in our country. Due to their biodegradability and eco toxicological acceptability, natural plant preparations are very popular with farmers in organic agriculture. This type of preparations has long been used on smaller farms in poor countries (Roy et al. 2005). Plant infusions can be a significant source of various trace elements for 
plants, depending on the plant species and the quality of the soil on which these plants are grown (Popescu et al. 2010).

The production of berries according to the concept of organic food production, in the Republic of Srpska and Bosnia and Herzegovina is mainly focused for own needs and takes place on small areas. From the financial point of view, the economic sustainability of organic agriculture in $\mathrm{B} \& \mathrm{H}$ would be possible if there was a demand for the consumption of organic food or conditions for its export (Vaško and Kovačević 2020). The planned establishment of blackberry plantations based on the concept of organic production, was initiated in our country at the end of the 1990s with the help of donated funds. Currently, the largest blackberry plantation in B\&H is located in Srebrenica, with a total area of 9.5 ha.

Blackberry fruits are an excellent laxative, they contribute to better digestion of food, improve blood count, regulate blood pressure and strengthen the body's resistance to arteriosclerosis and heart attack. Antioxidants found in blackberry fruits participate in preventing the harmful effects of free radicals, and thus occurrence of malignant diseases, they protect the cardiovascular system, slow down the aging of the body, and help fight the harmful effects of the sun on the skin. The nutritional value of blackberry fruit is reflected in the content of a large number of different compounds whose quantity depends on the variety, ecological conditions, applied cultivating practices, yield and degree of maturity at harvest (Nikolić, 2004).

It is estimated that cultivated blackberries are grown on more than 25000 ha worldwide (Fernandez and Ballington, 2014). The yield of blackberry fruit in the conventional production of the varieties Thornfree, Thornes logan and Gente del Giardino (Giant) in favorable conditions ranges from 22000 to $25000 \mathrm{~kg}$ ha ${ }^{1}$, and in the variety Smoothstem up to $30000 \mathrm{~kg} \mathrm{ha}^{-1}$, but on poorer soils yield falls below $15000 \mathrm{~kg} \mathrm{ha}^{-1}$ (Stančević, 1990). The yields of blackberries grown in our agro-ecological conditions can reach up to $20000 \mathrm{~kg} \mathrm{ha}^{-1}$ (Osmancevic and Brzica, 1991). The yield of blackberry cultivar Onyxa in the conventional method of production averaged $14000 \mathrm{~kg} \mathrm{ha}^{-1}$ (Finn et al., 2011). The obtained yield of blackberry fruit grown in organic production in 2012 was $7400 \mathrm{~kg} / \mathrm{plant}$ (Fernandez-Salvador et al., 2015). Zavišić et al. reported that blackberry plants in organic production treated with nettle solution F-14 had the average yield of 10 $550 \mathrm{~kg} \mathrm{ha}^{-1}$, and $10260 \mathrm{~kg} \mathrm{ha}^{-1}$ when treated with F-21 nettle solution. The average yield of ripe fruit obtained from blackberry plants treated with F-14 dandelion solution was $10210 \mathrm{~kg} \mathrm{ha}^{-1}$, and for those treated with F-21 solution was $10370 \mathrm{~kg} \mathrm{ha}^{-1}$. The average yield of ripe blackberry fruit from plants treated with alfalfa solution F-14 was $10190 \mathrm{~kg} \mathrm{ha}^{-1}$, and the application of F-21 treatment had yield of $10970 \mathrm{~kg} \mathrm{ha}^{-1}$. An average yield of $9015 \mathrm{~kg} \mathrm{ha}^{-1}$ of blackberry fruit was obtained in the control (Zavišić et al., 2015). 
The aim of this study was to examine the influence of infusions prepared with different plants and fermentation periods on the content of soluble dry matter and the dry matter yield of blackberry fruit grown in organic production.

\section{MATERIAL AND METHODS}

Experimental studies on the influence of nettle, dandelion and alfalfa infusions on the content of soluble and dry matter yield in blackberry fruit were performed in an organic blackberry plantation in the area of Kozarska Dubica, B\&H. Field trials and laboratory testing lasted two years. For the treatment of blackberry plants, nettle, dandelion and alfalfa infusions were prepared with different fermentation periods, namely for 14 days and 21 days. Young plants of nettle, dandelion and alfalfa were used for the preparation of infusions. After harvesting, the plants were finely chopped and immersed in pots previously filled with rainwater. The nettle infusion was prepared by adding $1 \mathrm{~kg}$ of chopped young nettle plants to the pots with rainwater. For the preparation of dandelion and alfalfa infusions, $2 \mathrm{~kg}$ of young chopped plants were used. There were a total of 6 vessels, i.e. three for the preparation of solutions with a fermentation period of 14 days, and three with a fermentation period of 21 days. During the fermentation, the pots with chopped plants were kept in the shade and the contents of the pots were occasionally stirred. After the end of the fermentation cycles of 14 and 21 days, the plant infusions were filtered, and then diluted with distilled water in a ratio of 1:10.

Before the use of plant solutions, the control of their safety and chemical composition was performed. Microbiological control of plant infusions was performed at the Veterinary Institute "Vaso Butozan" in Banja Luka. The presence of following bacteria was examined in the extracts: Salmonella, Staphylococcus, Clostridium, Proteus species and Escherichia coli. Chemical analysis was performed in the laboratory of the Department of Agroecology at the Agricultural Institute of Republic of Srpska in Banja Luka.

The Čačanska bestrna variety was planted in an organic blackberry orchard. The distance between the blackberry bushes was $3 \mathrm{~m} \times 1.5 \mathrm{~m}$. The experimental trial on the blackberry plantation was set up according to a random block system in 4 replications. Each replicate consisted of five blackberry bushes.

During these tests, the first treatment with plant infusions was performed in mid-May, followed by treatments every 10 to 15 days until the appearance of the first ripe blackberry fruits. The treatments were performed with a Villager DM-25 motor sprayer.

The first harvest of ripe blackberry fruits was in the mid-July in the phase of physiological maturity. By the end of August, the blackberry fruits were selectively harvested on six occasions. Blackberry fruits were harvested from all zones of the bush; five fruits from each top, middle and lower part of the plant. The following properties were analyzed: chemical composition of plant infusions, content of soluble dry matter in blackberry fruit and dry matter yield of 
blackberry fruit. Measurement of soluble dry matter content in blackberry fruit was performed with a manual refractometer MR200ATC, and the values were expressed as a percentage. The dry matter content was determined by drying $10.00 \mathrm{~g}$ of fresh blackberries in an oven at $105{ }^{\circ} \mathrm{C}$ up to a constant weight. Dry matter yield per unit area was calculated based on the blackberry fruit yield and dry matter content in blackberry fruits.

The obtained results were processed by the statistical method of analysis of variance (ANOVA), and the significance of the differences in the mean values was determined by the LSD test.

Agro ecological conditions: Soil samples for the chemical analysis were collected in a depth of $0-40 \mathrm{~cm}$ from the blackberry plantation grown in organic production before the experiment. Chemical analysis of the soil samples was performed in the laboratory for agrochemistry of the Faculty of Agriculture, Novi Sad. The weather conditions in the area where the experiment was performed were monitored during the course of research. For that purpose, the data of the Hydro-meteorological station at the Mlječanica site, which is located in the northwest of the Republika Srpska, B\&H were used. The average amount of precipitation in the vegetation period was higher in relation to the perennial average $(442.7 \mathrm{~mm})$. The average air temperatures during the vegetation period (IV-VIII) were at the level of perennial average $\left(18.9^{\circ} \mathrm{C}\right)$, with slight deviations.

\section{RESULTS AND DISCUSSION}

The blackberry plantation was established on the brown earth soil, which is characterized by a favorable water-air regime. The results of chemical analysis of soil samples taken before the start of the research are shown in Table 1.

Table 1. Results of soil chemical analysis

\begin{tabular}{|c|c|c|c|c|c|c|c|}
\hline $\begin{array}{c}\text { Depth } \\
(\mathrm{cm})\end{array}$ & $\begin{array}{c}\mathrm{pH} \\
\text { in } \\
\mathrm{KCl}\end{array}$ & $\begin{array}{c}\mathrm{pH} \\
\text { in } \\
\mathrm{H}_{2} \mathrm{O}\end{array}$ & $\begin{array}{c}\mathrm{Humus} \\
(\%)\end{array}$ & $\begin{array}{c}\mathrm{P}_{2} \mathrm{O}_{5} \\
\mathrm{mg} / 100 \mathrm{~g}\end{array}$ & $\begin{array}{c}\mathrm{K}_{2} \mathrm{O} \\
\mathrm{mg} / 100 \mathrm{~g}\end{array}$ & $\begin{array}{c}\mathrm{Pb} \\
\left(\mathrm{mg} \mathrm{kg}^{-}\right.\end{array}$ & $\begin{array}{c}\mathrm{Cd} \\
\left(\mathrm{mg} \mathrm{kg}^{-}\right.\end{array}$ \\
\hline $0-40$ & 6.95 & 7.67 & 3.21 & 9.72 & 20.68 & 15.5 & 1.78 \\
\hline
\end{tabular}

The results of soil analyses showed that the blackberry plantations were established on the soil with $\mathrm{pH}$ value of 7.67 in water, while $\mathrm{pH}$ in $\mathrm{KCl}$ was 6.95. Based on the $\mathrm{pH}$ results, this soil is considered to be a soil with a slightly alkaline reaction. According to the humus content, which was $3.21 \%$, this soil is considered to be moderately supplied. The content of easily accessible phosphorus at a depth of $0-40 \mathrm{~cm}$ was low, $9.72 \mathrm{mg} 100 \mathrm{~g}^{-1}$. The soil contained $20.38 \mathrm{mg} 100 \mathrm{~g}^{-1}$ of $\mathrm{K}_{2} \mathrm{O}$ and was well provided with this biogenic element. The content of heavy metals and potentially toxic elements in agricultural soil, lead and cadmium, was below the limit allowed in the soil intended for organic production. Based on chemical analysis of the soil sample from a depth of 0-40 $\mathrm{cm}$, it can be concluded that it was suitable for organic blackberry production. 
Before the beginning of foliar application of plant infusions obtained from nettle, dandelion and alfalfa, analysis of their chemical composition and microbiological safety was performed. Microbiological control confirmed that plant infusions were safe for use in organic blackberry production. The results of chemical analysis of infusions after 14 and 21 days of fermentation are presented in Table 2.

Table 2. Chemical composition of plant infusions after 14 and 21 fermentation days

\begin{tabular}{|l|c|c|c|c|c|}
\hline \multirow{2}{*}{$\begin{array}{c}\text { Plant } \\
\text { infusion }\end{array}$} & $\begin{array}{c}\text { No. of } \\
\text { fermentation } \\
\text { days }\end{array}$ & $\mathrm{pH}$ value & $\begin{array}{c}\mathrm{N} \\
\left(\mathrm{mg} \mathrm{l}^{-1}\right)\end{array}$ & $\begin{array}{c}\mathrm{P} \\
\left(\mathrm{mg} \mathrm{l}^{-1}\right)\end{array}$ & $\begin{array}{c}\mathrm{K} \\
\left(\mathrm{mg} \mathrm{l}^{-1}\right)\end{array}$ \\
\hline \multirow{2}{*}{ Nettle } & $\mathrm{F}-14$ & 6.4 & 56.8 & 56.3 & 700.2 \\
\cline { 2 - 6 } Dandelion & $\mathrm{F}-21$ & 6.5 & 53.9 & 55.4 & 695.9 \\
\cline { 2 - 6 } & $\mathrm{F}-14$ & 5.2 & 41.0 & 42.5 & 1205.3 \\
\hline \multirow{2}{*}{ Alfalfa } & $\mathrm{F}-21$ & 5.2 & 45.4 & 44.9 & 1245.7 \\
\cline { 2 - 6 } & $\mathrm{F}-14$ & 5.4 & 105.6 & 40.2 & 670.4 \\
\hline
\end{tabular}

After 14 days of fermentation, the $\mathrm{pH}$ value of the nettle infusion was weakly acidic (6.4), while that of dandelion (5.2) and alfalfa (5.4) was acidic. After 21 days of fermentation, the $\mathrm{pH}$ value of the nettle infusion was slightly higher (6.5), but still weakly acidic. The $\mathrm{pH}$ value of the dandelion solution remained unchanged after 21 days of fermentation (5.2), while the value of the alfalfa infusion increased slightly, but the solution was still acidic. After 14 days of fermentation, the nettle infusion had a nitrogen content of $56.8 \mathrm{mg} \mathrm{l}^{-1}$, phosphorus $56.3 \mathrm{mg} \mathrm{l}^{-1}$ and potassium $700.2 \mathrm{mg} \mathrm{l}^{-1}$. After 21 days of fermentation, a chemical analysis of the nettle solution revealed a slightly lower content of all examined macroelements, and the largest decrease was in the content of potassium $\left(695.9 \mathrm{mg} \mathrm{l}^{-1}\right)$. The dandelion infusion obtained after 14 days of fermentation had a nitrogen content of $41.0 \mathrm{mg} \mathrm{l}^{-1}$, phosphorus $42.5 \mathrm{mg} \mathrm{l}^{-1}$ and potassium $1005.3 \mathrm{mg} \mathrm{l}^{-1}$. The content of potassium in the dandelion infusion was higher than in both nettle and alfalfa infusions. In the F-21 dandelion infusion, a slight increase in all tested macronutrients was found, and the largest increase was in the potassium content $\left(1245.7 \mathrm{mg} \mathrm{l}^{-1}\right)$. At the same time, in the F21 alfalfa infusion, a lower content of nitrogen, phosphorus and potassium was determined compared to the content in the solution that was obtained after 14 days of fermentation. The largest decrease was in the nitrogen content $(101.7 \mathrm{mg}$ $\left.1^{-1}\right)$.

Blackberry fruit contains a large number of different organic and inorganic ingredients, which have nutritional, medicinal and protective value. The content of soluble dry matter in blackberry fruit can vary, depending on several factors (agro-ecological conditions, variety characteristics, degree of fruit maturity, yield, etc.). Farming practices affect the content of soluble dry matter which is higher in 
production where chemical plant protection is used compared to the organic method of cultivation where pesticides are not used (Schneider et al. 2011). The content of mineral substances of certain elements $(\mathrm{P}, \mathrm{K}$ and $\mathrm{Mg}$ ) is higher in organic than in conventional production.

During this research, the content of soluble dry matter in ripe blackberry fruits that were harvested from plants treated with nettle, dandelion and alfalfa infusions was monitored, and the results are shown in Table 3.

Table 3. Dry matter content (\%) in ripe blackberry fruit treated with different infusions

\begin{tabular}{|c|c|c|c|c|c|}
\hline \multirow{2}{*}{\multicolumn{2}{|c|}{ Fermentation period }} & \multicolumn{4}{|c|}{ Plant infusion } \\
\hline & & Control & Nettle & Dandelion & Alfalfa \\
\hline \multicolumn{2}{|c|}{ F-14 } & 9.24 & 9.43 & 9.20 & 9.32 \\
\hline \multicolumn{2}{|c|}{ F-21 } & 9.20 & 9.07 & 9.51 & 8.80 \\
\hline \multicolumn{2}{|c|}{$\bar{X}$} & 9.22 & 9.25 & 9.36 & 9.06 \\
\hline \multicolumn{2}{|c|}{ Level } & $\mathrm{A}$ & \multicolumn{2}{|r|}{ B } & $\mathrm{AB}$ \\
\hline \multirow{2}{*}{ LSD } & 0.05 & $0.52^{\mathrm{n}}$ & \multicolumn{2}{|c|}{$0.37 *$} & $0.72^{\mathrm{ns}}$ \\
\hline & 0.01 & $0.70^{\mathrm{n}}$ & \multicolumn{2}{|c|}{$050 * *$} & $0.98^{\mathrm{ns}}$ \\
\hline
\end{tabular}

A-plant infusion; B-fermentation period; AB-interaction; ns-not significant; $*$ significant at $\mathrm{p}<0.05 ; * *$ very significant at $\mathrm{p}<0.01$

The average values of soluble dry matter content in ripe blackberry fruits harvested from the control variant F-14 was 9.24\%, while in the control variant F21 the determined value was slightly lower, $9.20 \%$. The highest content of soluble dry matter in blackberry fruit was found after treatment with F-21 dandelion extract $(9.51 \%)$, and the lowest after treatment with alfalfa extract of the same number of fermentation days $(8.80 \%)$. No statistically significant differences in the content of soluble dry matter in ripe blackberry fruits were found between control and the applied plant infusion treatments. At the same time, statistically highly significant differences in the content of soluble dry matter in blackberry fruits harvested from shrubs treated with alfalfa infusions with different number of fermentation days were observed. Blackberry fruits treated with F-14 alfalfa infusion had a higher content of soluble dry matter $(9.32 \%)$ than fruits harvested from shrubs treated with F-21 solution $(8.80 \%)$. Treatments of blackberry fruits with plant solutions that had higher content of nitrogen and potassium resulted in higher content of soluble dry matter in fruits (Table 2). Changes in the content of soluble dry matter in blackberry fruits treated with plant infusions prepared with two fermentation periods are shown in Graph 1.

The content of soluble dry matter in ripe blackberry fruits can vary from 10 to $14 \%$ (Gavrilović and Janda 1977, Šoškić, 1984). According to the results reported by Nikolić (2004), ripe blackberry fruits contain 9-14\% of soluble dry matter, while in wild blackberries the content of these substances varied from 6 to 
13.1\%. In addition to climatic conditions during the ripening period, the content of soluble dry matter in the fruit is significantly influenced by the cultivated variety. In the research of Milošević et al. (2012) cultivar Čačanska bestrna had the lowest content of soluble dry matter compared to other cultivars in the experiment. The content of soluble dry matter does not change significantly during storage in most blackberry varieties (Repajić et al. 2019). During a twoyear experiment with organically grown blackberry varieties Black Diamond, Metolius, ORUS 1939-4, ORUS 2635-1, Obsidian and Onyx, the content of soluble dry matter in ripe fruits varied from $11.2 \%$ to $14.4 \%$ (FernandezSalvador et al., 2015). The content of soluble dry matter in wild blackberries grown in Croatia ranged from 9.4-11.5\% (Purgar-Dujmović et al., 2012). The yield of blackberry dry matter depends on a number of factors, and particularly assortment, cultivation system, applied farming practices and agro-ecological conditions. The dry matter yields obtained in our study are presented in Table 4.

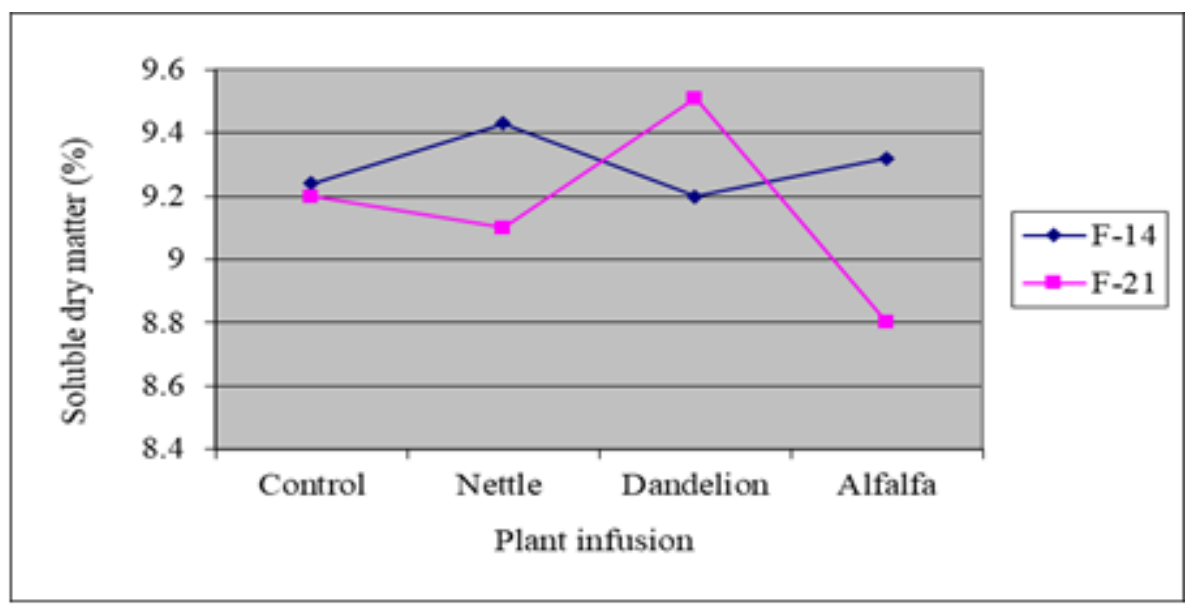

Graph 1. Content of soluble dry matter in blackberry fruits treated with infusions of nettle, dandelion and alfalfa relative to control

The average dry matter yield of blackberry fruits per unit area was the lowest in the control. The obtained dry matter yields of blackberry fruits in the treatments with F-14 nettle and dandelion infusions were higher compared to the treatments with F-21. At the same time, in the treatment with alfalfa solution the opposite was found, i.e., higher yields of fruit dry matter were achieved with F-21 treatment. The differences in the dry matter yields of blackberry fruits between control and treatment with F-14 solution were statistically significant. There were also statistically significant differences between the control treatment and the treatments with F-21 dandelion and alfalfa infusions.

Statistically highly significant differences in the dry matter yield of blackberry fruits were found between the control treatment and the F-14 and F-21 alfalfa infusion treatments. The highest yield of dry matter of blackberry fruits 
was achieved with the application of F-21 alfalfa solution (1 $\left.327.4 \mathrm{~kg} \mathrm{ha}^{-1}\right)$. The differences in the dry matter yield of blackberry fruits between the applied treatments with infusions of different fermentation periods were not statistically significant. Changes in dry matter yield in blackberry fruits treated with the solutions from different plants with two fermentation periods are shown in Graph 2.

Table 4. Average yield of blackberry dry matter $\left(\mathrm{kg} \mathrm{ha}^{-1}\right)$ treated with plant infusions

\begin{tabular}{|c|c|c|c|c|c|}
\hline \multirow{2}{*}{\multicolumn{2}{|c|}{ Fermentation period }} & \multicolumn{4}{|c|}{ Plant infusion } \\
\hline & & Control & Nettle & Dandelion & Alfalfa \\
\hline \multicolumn{2}{|c|}{ F-14 } & 1028.0 & 1254.9 & 1255.4 & 1265.3 \\
\hline \multicolumn{2}{|c|}{ F-21 } & 1001.0 & 1169.6 & 1223.4 & 1327.4 \\
\hline \multicolumn{2}{|c|}{$\bar{X}$} & 1014.5 & 1212.3 & 1239.4 & 1296.4 \\
\hline \multicolumn{2}{|c|}{ Level } & \multicolumn{2}{|l|}{ A } & \begin{tabular}{l|l} 
B & \\
\end{tabular} & \multirow{2}{*}{$\frac{\mathrm{AB}}{246.4^{\mathrm{ns}}}$} \\
\hline \multirow{2}{*}{ LSD } & 0.05 & $174.2^{*}$ & & $123.2^{\mathrm{ns}}$ & \\
\hline & 0.01 & $236.1 *$ & & $6.9^{\mathrm{ns}}$ & $333.9^{\text {ns }}$ \\
\hline
\end{tabular}

A-plant infusion; B-fermentation period; AB-interaction; ns-not significant; *significant at $\mathrm{p}<0.05 ; * *$ very significant at $\mathrm{p}<0.01$

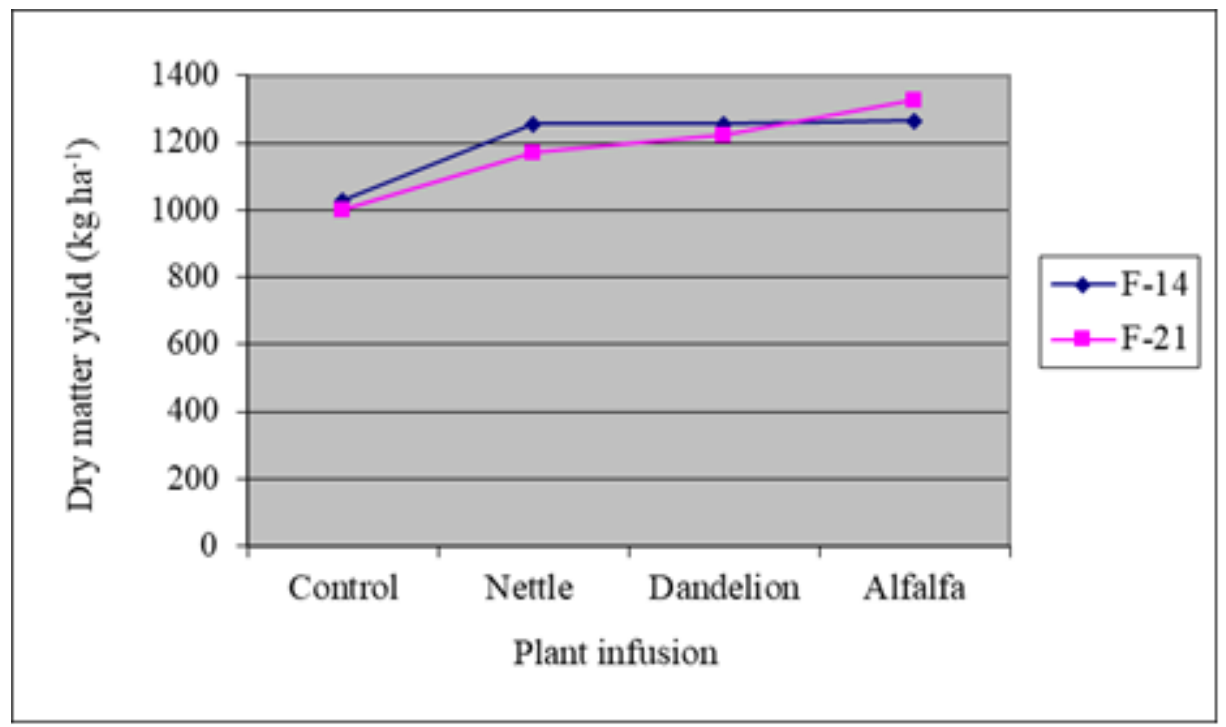

Graph 2. Dry matter yield in blackberry fruits treated with infusions of nettle, dandelion and alfalfa relative to control

\section{CONCLUSIONS}

Based on the chemical analysis of the soil sample from a depth of $0-40 \mathrm{~cm}$, it can be concluded that it was a weakly alkaline and suitable for organic 
blackberry production. The content of heavy metals and potentially toxic elements lead, and cadmium was below the limits allowed in the soil intended for organic production. Microbiological tests have shown that nettle, dandelion and alfalfa infusions are safe and can be used for foliar treatment of blackberry in organic production.

The type of plant and the length of the fermentation period influenced the $\mathrm{pH}$ value of the plant solution. After 14 and 21 days of fermentation, the $\mathrm{pH}$ value of the nettle infusion was slightly acidic, while dandelion and alfalfa solutions were acidic. The tested plant infusions can be used in organic production as a good source of N, P and K. F-14 and F-21 alfalfa infusions had the highest content of nitrogen (105.6 $\mathrm{mg} \mathrm{l}^{-1}$ and $101.7 \mathrm{mg} \mathrm{l}^{-1}$ respectively), while the $\mathrm{F}-14$ and F-21 dandelion infusions had the highest potassium content $\left(1205.3 \mathrm{mg} \mathrm{l}^{-1}\right.$ and $1245.7 \mathrm{mg} \mathrm{l}^{-1}$, respectively). Fermentation period did not significantly affect the content of elements in the individual plant infusions.

The highest content of soluble dry matter in ripe blackberry fruits was obtained after treatment with F-21 dandelion extract (9.51\%). The highest yield of dry matter of blackberry fruits was achieved with the application of F-21 alfalfa infusion (1 $\left.327.4 \mathrm{~kg} \mathrm{ha}^{-1}\right)$.

The use of plant infusions in organic blackberry production increased the average dry matter yield.

\section{REFERENCES}

Boshev, D., Jankulovska, M., Tanaskovik, V., Ivanovska, S., Spalevic, V., Karakolevski, D. (2016): Assessment of yield and quality of spring barley depending of foliar fertilization. Agriculture and Forestry, 62 (1): 269-278.

Daoubi, M., Deligeorgopoulou, A., Macias-Sanchez, AJ., Hermamdez-Galan, R., Hitchcock PB., Hanson, JR., Collado, IG. (2005): Antifungal activity and biotransformation of diisophorone by Botrytiscinerea. Journal of Agricultural and Food Chemistry 53:6035-6039.

Fernandez, V., Eichert, T. (2009): Uptake of hydrophilic solutes through plant leaves: Current state of knowledge and perspectives of foliar fertilization. Critical Reviews in Plant Science 28:36-68.

Fernandez, G., Ballington, R.J. (2014): Horticulture Growing Blackberries in North Carolina. Revista Brasileira de Fruticultura 36(1):46-57.

Fernandez-Salvador, J., Strik, C.B., Zhao, Y., Finn, E.Ch. (2015): Trailing blackberry genotypes differ in yield and postharvest fruit quality during establishment in an organic production system. HortScience 50(2):240-246.

Finn, C.E., Strik, B.C., Yorgey, B.M., Martin, R.R. (2011): 'Onyx' trailing blackberry. HortScience (4):657-659.

Gavrilović, J., Janda, LJ. (1977): Uticaj načina gajenja jagoda na biohemijske osobine ploda, Jugoslovensko voćarstvo 20:75-76.

Hoitink, A., Staone, J.A.G., Han, D.Y. (1997): Suppression of plant diseases by composts. (rparticle.web-p.cisti.nrc.ca/.../AbstractTemplateServlet).

Kim, HG., Jeon, J.H, Kim, M.K., Lee, H.S. (2005): Pharmacological ectsofasaron aldehyde isolated from Acorusgram in eusrhizome. Food Science Biotechnology. 14(5):685-688. 
Milošević, T., Milošević, N., Glišić, I., Mladenović, J. (2012): Fruit quality attributes of blackberry grown under limited environmental conditions. Plant Soil Environment, $58(7): 322-327$.

Nikolić, M. (2004): Tehnologija proizvodnje kupine. Grafika Jureš, Čačak, p. 32.

Osmančević, M., Brzica, K. (1991): Voćarstvo-pitanja, odgovori i slike. Zadrugar, Sarajevo, p. 204.

Popescu, M., Dune, A., Ivopol, G., Ionescu, D. (2010): Powders And Extracts Of Plants As An Interesting Source Of Bioavailable Minerals. A Focus Upon The Mineral Content Of Certain Agricultural Soils. Proceeding of the International Conference BIOATLAS 2010 Transilvania University of Brasov, Romania.

Purgar-Dujmović, D., Duralija, B., Voća, S., Vokurka, A., Ercisli, S. (2012): A Comparison of Fruit Chemical Characteristics of Two Wild Grown Rubus Species from Different Locations of Croatia. Molecules. 17(9): 10390-10398.

Quarles, W. (2001): Compost tea for organic farming and gardening. The IPM Practitioner. 23(9):1-8.

Repajić, M., Markov, K., Frece, J., Vujević, P., Ćurić, D., Levaj, B. (2019): Studija kvaliteta plodova više vrsta jagodastog voća tijekom skladištenja. Glasnik zaštite bilja 4/2019: 68-81.

Roy, B., Amin, R., Uddin, M.N., Islam, A.T.M.S., Islam, M.J., Halder, B.C. (2005): Leaf extracts of Shiyalmutra (Blumea lacera Dc.) as botanical pesticides against lesser grain borer and rice weevil. Journal of Biological Sciences 5(2):201-204.

Stančević, A. (1990): Praktično voćarstvo. Litopapir, Čačak, p. 285.

Šoškić, A. (1984): Kupina. Zadrugar, Sarajevo, p.152.

Vaško, Ž., Kovačević, I. (2020): Comparison of economic efficiency of organic versus conventional farming in the conditions of Bosnia and Herzegovina. Agriculture and Forestry, 66(2):167-178.

Zavišić N., Rosić Ž., Lakić Ž., Kapić M. (2015): Efficacy of plant extracts application on suppression of Botrytis cinerea and impact on blackberries yield. Contemporary Agriculture 64(3-4):200-205. 